Tropical Journal of Pharmaceutical Research June 2021; 20 (6): 1139-1144

ISSN: $1596-5996$ (print); 1596-9827 (electronic)

(C) Pharmacotherapy Group, Faculty of Pharmacy, University of Benin, Benin City, 300001 Nigeria.

Available online at http://www.tjpr.org

Original Research Article

http://dx.doi.org/10.4314/tjpr.v20i6.6

\title{
Regulatory mechanism of miR-146a on MPTP-induced neuroinflammation in mice with Parkinson's disease
}

\author{
Xuqing Cao1, Jiangtao Guo ${ }^{2 *}$, Hidek Mochizuki ${ }^{3}$, Zhimin Shi ${ }^{4}$, Peilan Zhang ${ }^{5}$, \\ Zhimei Liu ${ }^{4}$, Tao Zhang ${ }^{4}$, Jinxi $\mathbf{Q i}^{4}$, Dong $\mathrm{Xu}^{4}$ \\ ${ }^{1}$ Department of Neurology, People's Hospital of Ningxia Hui Autonomous Region (The Affiliated People's Hospital of Ningxia \\ Medical University and The First Affiliated Hospital of Northwest Minzu University), Yinchuan 750002, ${ }^{2}$ Department of \\ Rheumatogy and Immunology, People's Hospital of Ningxia Hui Autonomous Region (The Affiliated People's Hospital of \\ Ningxia Medical University and The First Affiliated Hospital of Northwest Minzu University), Yinchuan 750002, China, \\ ${ }^{3}$ Department of Neurology, Osaka University Graduate School of Medicine, Osaka, Japan, ${ }^{4}$ Department of Neurology, People's \\ Hospital of Ningxia Hui Autonomous Region, Yinchuan 750002, ${ }^{5}$ Department of Neurology, Tianjin Huanhu Hospital, Tianjin \\ 300350, PR China
}

*For correspondence: Email: ckha04@163.com

\begin{abstract}
Purpose: To study the regulatory influence of microRNA-146a (miR-146a) on 1-methyl-4-phenyl-1,2,3, 6-tetrahydropyridine (MPTP)-induced neuroinflammation in mice with Parkinson's disease (PD).

Methods: Forty specific pathogen-free (SPF) male C57BL/6 mice were divided into 2 groups: normal control and PD groups. The 2 groups were each divided into 2 subgroups: miR-146a inhibitor and inhibitor control groups. The mRNA and protein expressions of miR-146a, interleukin-1 receptorassociated kinase-1 (IRAK-1) and P65-NF-KB were determined by quantitative real-time polymerase chain reaction ( $q R T-P C R)$ and immunoblot assay, respectively. Levels of interleukin (IL)-1, IL-6 and TNF- $\alpha$ were assayed by enzyme-linked immunosorbent assay (ELISA).

Results: The level of expression of miR-146a was significantly and time-dependently increased in PD mice, relative to control $(p<0.05)$. In PD group, mRNA and protein expressions of IRAK-1 were markedly higher in miR-146a inhibitor group than in inhibitor control $(p<0.05)$. Protein expression of $P 65-N F-K B$ was significantly upregulated in brains of $P D$ mice, relative to normal mice $(p<0.05)$. Moreover, IL-1, IL-6 and TNF- $\alpha$ levels were significantly higher in brains of PD mice than in control Conclusion: These results show the involvement of miR-146a in the etiology of $P D$, and that its regulation of neuroinflammation occurs via inhibition of IRAK1 gene expression. This finding may be useful in the development of new anti-PD drugs based on miR-146a.
\end{abstract}

Keywords: Inflammatory cytokines, IRAKI-1, MicroRNA-146a, Neuroinflammation, Parkinson's disease

\begin{abstract}
This is an Open Access article that uses a fund-ing model which does not charge readers or their institutions for access and distributed under the terms of the Creative Commons Attribution License (http://creativecommons.org/licenses/by/4.0) and the Budapest Open Access Initiative (http://www.budapestopenaccessinitiative.org/read), which permit unrestricted use, distribution, and reproduction in any medium, provided the original work is properly credited.
\end{abstract}

Tropical Journal of Pharmaceutical Research is indexed by Science Citation Index (SciSearch), Scopus, International Pharmaceutical Abstract, Chemical Abstracts, Embase, Index Copernicus, EBSCO, African Index Medicus, JournalSeek, Journal Citation Reports/Science Edition, Directory of Open Access Journals (DOAJ), African Journal Online, Bioline International, Open-J-Gate and Pharmacy Abstracts

\section{INTRODUCTION}

Parkinson's disease (PD), a degenerative disease of the CNS, is prevalent among older adults. It is characterized by tremor, myotonia and bradykinesia (reduced movement). The main pathological changes in PD are degeneration and death of dopaminergic neurons in substantia 
nigra of the brain. With a total incidence of $0.3 \%$, the disease ranks second only to Alzheimer's disease (AD) [1]. Parkinson's disease (PD) has a strong positive correlation with age [1]. The rise in its incidence places serious burden on the family of sufferers and society. Till date, the pathogenesis of PD is largely unknown, although it may entail environmental and genetic factors [2]. Studies have shown that damage to dopaminergic neurons in the substantia nigra results in mitochondrial dysfunction, neuronal immune response, inflammatory response, oxidative stress, apoptosis and autophagy. Moreover, defective mitochondrial function leads to apoptosis of dopaminergic neurons in dense area of substantia nigra. At present, there is a dearth of clinical biomarkers for early diagnosis of PD.

Only recently, the role of miRNA in the immune system received attention. A non-coding RNA with regulatory functions, miRNA participates in physiological processes of the cell via regulation of genes after transcription [4]. A role exists for miRNAs in the regulation of the progression of neurodegenerative diseases, including PD [5]. MicroRNA-146a (miR-146a) is highly expressed in the CNS. Its expression has been reported to be significantly downregulated in serum of patients with $A D$. It has also been demonstrated to promote inflammatory response of cells via increased expression of TLR2 gene [6]. The aim of this research was to study the regulatory mechanism of miR-146a on MPTP-induced neuroinflammation in PD mice.

\section{EXPERIMENTAL}

\section{Materials}

Ham's F-12 medium and DMEM were bought from Shanghai Fuze Trading Co. Ltd, while BCA protein kit was product of Beijing Kangjiahongyuan Biotechnology Co. Ltd. Antibodies for (IRAK-1) and P65-NF-KB were products of Wuhan IpU Biotechnology Co. Ltd. Alkaline phosphatase development kit and constant temperature horizontal shaker were obtained from Shanghai Caiyou Industrial Co. Ltd. Lipofectamine 2000 transfection reagent was bought from Shanghai Beinuo Biotechnology Co. Ltd. Protein pre-dyeing marker was product of Beijing Baoxentai Biotechnology Co. Ltd.

Enzyme-linked immunosorbent assay (ELISA) kit was obtained from Beijing Baiolaibo Technology Co. Ltd. Deionic formamide was bought from Shanghai Rongweida Industrial Co. Ltd. AxyPrep DNA gel recovery kit was product of Beijing Jiehuibo Biotech. Cryogenic centrifuge was bought from Sichuan Shuke Instrument Co. Ltd. Light microscope was purchased from Guangzhou Kexite Scientific Instruments Ltd. Constant temperature incubator was product of Hangzhou Nuoding Scientific Equipment Co. Ltd. Autoclave was bought from Nanjing Baden Medical Co. Ltd. Electrophoresis apparatus and tank were obtained from Hangzhou Bigo Flying Sequence Biotechnology Co. Ltd. Thermostatic water bath was bought from Shanghai Tibose Biotechnology Co. Ltd. Spectrophotometer was product of Beijing Jinda Sunshine Technology Co. Ltd. Quantitative PCR machine was bought from Shanghai Aiyan Biotechnology Co. Ltd., while brain stereo locator was obtained from Nanjing Calvin Biotechnology Co. Ltd.

\section{Mice}

Specific-pathogen-free (SPF) male C57BL/6 mice $(n=40)$ aged 8 - 10 weeks and weighing $20-26 \mathrm{~g}$ (mean age $=9 \pm 1$ weeks; mean weight $=23 \pm 3 \mathrm{~g}$ ) were purchased from Beijing Weitong Lihua Laboratory Animal Technology Co. Ltd. The mice were accommodated in plastic cages under equal light/dark photoperiod, and were permitted unlimited access to water and feed. The study protocol received approval from the Institutional Animal Ethics Committee of People's Hospital of Ningxia Hui Autonomous Region (Approval No.200903041), according to "Principles of Laboratory Animal Care" (NIH publication no. 85-23, revised 1985) [7].

Two groups of mice were used, each with 20 animals: normal control and PD groups. The 2 groups were each divided into 2 subgroups (5 mice/group): miR-146a inhibitor and inhibitor control groups. Parkinson's disease was induced with single i.p. administration of MPTP (30 $\mathrm{mg} / \mathrm{kg}$ ). Normal control mice received equivalent volume of normal saline. The mice were euthanized at different time points: day 0, 1, 5, 10 and 20 post-induction. Complete brain tissue of each mouse was excised and the midbrain removed and used for biochemical analysis. Moreover, lateral ventricles of mice in the subgroups were injected with miR-146a inhibitor or inhibitor control. Two days after induction of PD, the mice were anesthetized and dissected to obtain brain tissues which were stored at $-80{ }^{\circ} \mathrm{C}$ prior to analysis.

\section{qRT-PCR assay}

After thawing, frozen mouse brain was homogenized with TRizol reagent. Total RNA was also obtained with TRIzol extraction, and its quality and concentration were measured colorimetrically. The total RNA was then 
converted to cDNA according to the instructions of reverse transcription kit. Reverse transcription was carried out on PCR machine at $42^{\circ} \mathrm{C}$ for 50 min, with incubation for $5 \mathrm{~min}$ at $95{ }^{\circ} \mathrm{C}$. The synthesized cDNA was amplified via PCR for determination of the expression levels of miR146a, IRAK1 and P65-NF-KB under standard assay conditions. The relative mRNA levels were estimated using $2^{-\Delta \Delta C t}$ procedure, with $\beta$-actin as standard gene.

Table 1: The primers used in PCR

\begin{tabular}{ll}
\hline Gene & Primer sequence \\
\hline \multirow{2}{*}{ IRAK1 } & F: TGACTTCAGCCGCTACTTCC \\
& R: GTTCAGCTGTAGCCGAGAGT \\
\multirow{2}{*}{ U6 } & F: GCAGTCAACGGATTTGGT \\
& R: GTGATGGGATTTCCATTGAT \\
\hline
\end{tabular}

\section{Immunoblotting}

Mice brain tissues were homogenized with PBS and lysed with cold RIPA buffer in the presence of inhibitors of protease and phosphatase (PMSF). The protein content was measured with BCA method. Then, 30- $\mu$ g protein portions were resolved via SDS-PAGE and transferred to PVDF membrane. Subsequently, the membrane was incubated with $5 \%$ fat-free milk solution to achieve sealing. Thereafter, the membrane was incubated for $12 \mathrm{~h}$ at $4{ }^{\circ} \mathrm{C}$ with $1: 1000$ diluted $1^{\circ}$ antibodies for miR-146a, IRAK1, P65-NF-KB and $\beta$-actin, followed by incubation with HRP-linked $2^{\circ}$ antibody for $60 \mathrm{~min}$ at laboratory temperature. Blot development was performed with X-ray film, while ImageJ Launcher software was used for Grayscale analysis. Protein expression levels were calculated relative to $\beta$-actin which served as standard.

\section{ELISA}

The levels of IL-1, IL- 6 and TNF- $\alpha$ were determined using ELISA. Mid-brain tissues of mice were homogenized with ice-cold normal saline and centrifuged at $3500 \mathrm{rpm}$ for $10 \mathrm{~min}$ to obtain clear supernatant which was stored overnight at $4{ }^{\circ} \mathrm{C}$. After washing with PBS for 1 min, $200 \mu \mathrm{L}$ of blocking solution was added, and after $1 \mathrm{~h}$, washing was done thrice with PBS within 3 min. Blank control, standard and sample were added to their respective wells and incubated for $1 \mathrm{~h}$ at $37^{\circ} \mathrm{C}$. The mixture was rinsed with PBS for $3 \mathrm{~min}$. This was followed by the addition of enzyme-labeled secondary antibody, and after $30 \mathrm{~min}$, rinsing was done with PBS for $3 \mathrm{~min}$. Exactly $50 \mu \mathrm{L}$ of substrate $A / B$ was put in well and incubated for $20 \mathrm{~min}$ at 37 ${ }^{\circ} \mathrm{C}$. After a 10-min agitation, the optical density of each well was determined at $450 \mathrm{~nm}$.

\section{Statistics}

Measurement results are presented as mean \pm SEM, and were statistically analyzed with SPSS (21.0). Group comparisons were done with $t$-test, with $p<0.05$ indicating statistically significant differences.

\section{RESULTS}

\section{Expression level of miR-146a in brain tissues of mice with PD}

The level of expression of miR-146a was significantly and time-dependently increased in PD mice, relative to normal control group (Figure 1).

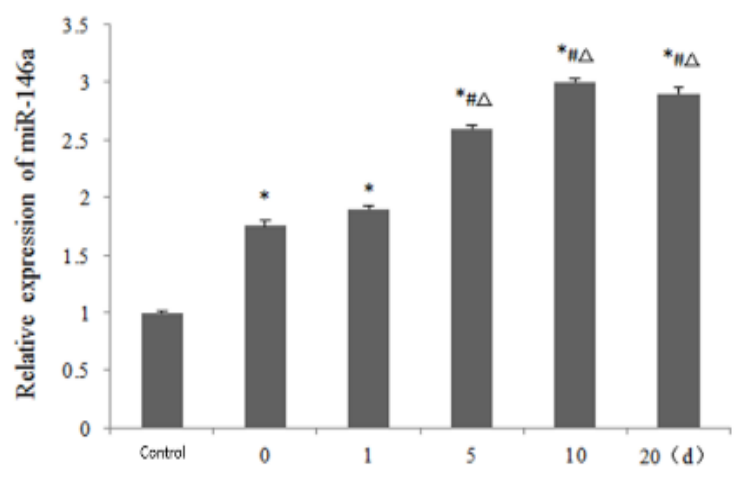

Figure 1: Expression level of miR-146a in mice brain tissues. ${ }^{*} P<0.05$, vs control; ${ }^{*} p<0.05$, vs day 0 ; ${ }^{*} \Delta p<$ 0.05 , vs day $1 ;{ }^{\#} \Delta p<0.05$, vs day 5

\section{Expression levels of IRAK-1 mRNA and protein in mice brain tissues}

These were markedly lower in brain tissues of PD mice than in normal control mice $(p<0.05)$. In PD group, IRAK-I mRNA and protein were markedly higher in miR-146a inhibitor subgroup than in inhibitor control subgroup (Table 2).

Table 2: Comparison of IRAK-1 mRNA and protein expressions in mice brain tissues

\begin{tabular}{|c|c|c|c|}
\hline \multicolumn{2}{|l|}{ Group } & $\begin{array}{l}\text { IRAK-1 } \\
\text { mRNA }\end{array}$ & $\begin{array}{l}\text { IRAK-1 } \\
\text { protein }\end{array}$ \\
\hline Normal & MiR-146a & $1.08 \pm$ & $1.11 \pm 0.17$ \\
\hline & $\begin{array}{l}\text { Inhibitor } \\
\text { control }\end{array}$ & $\begin{array}{l}1.02 \pm \\
0.01\end{array}$ & $1.00 \pm 0.01$ \\
\hline $\begin{array}{l}\text { Parkinson's } \\
\text { disease }\end{array}$ & $\begin{array}{l}\text { MiR-146a } \\
\text { inhibitor }\end{array}$ & $\begin{array}{l}0.90 \pm \\
0.06^{*}\end{array}$ & $0.95 \pm 0.12^{* \#}$ \\
\hline & $\begin{array}{l}\text { Inhibitor } \\
\text { control }\end{array}$ & $\begin{array}{l}0.71 \pm \\
0.08^{*}\end{array}$ & $0.60 \pm 0.07^{*}$ \\
\hline
\end{tabular}

inhibitor control in PD mice 
Expression levels of NF-KB protein in brains of mice with PD

As shown in Figure 2 and Figure 3, protein expression of P65-NF-kB was markedly increased in brains of mice with $\mathrm{PD}$, relative to normal control group. In contrast, in PD group, there was no marked difference in P65-NF-KB protein expression between miR-146a inhibitor and inhibitor control subgroups.

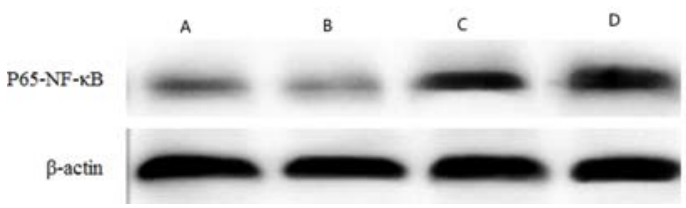

Figure 2: Levels of P65-NF-kB protein in each group, as measured using Western blotting. A. Normal control - miR-146a inhibitor; B. Normal control Inhibitor control; C. Parkinson's disease - miR-146a inhibitor; D. Parkinson's disease -Inhibitor control.

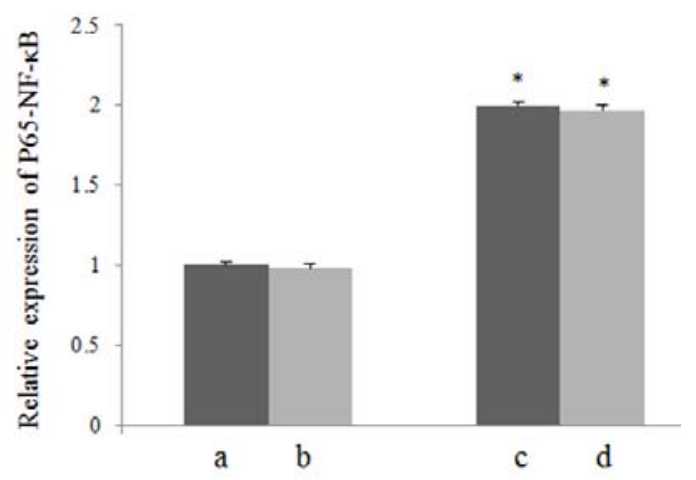

Figure 3: Expression level of P65-NF-KB protein in brain tissues of mice with PD. a. Normal controlInhibitor control; b. Normal control-miR-146a inhibitor; c. Parkinson's disease -Inhibitor control. d. Parkinson's disease-miR-146a inhibitor; " $p<0.05$, vs normal control group

\section{Levels of inflammatory cytokines in brain tissues of PD mice}

Table 3 and Figure 4 show that inflammatory cytokines were markedly higher in brains of PD mice than in normal control group, but the levels of these inflammatory cytokines were comparable between miR-146a inhibitor and inhibitor control subgroups in mice with PD.

\section{DISCUSSION}

Parkinsonism is a neurodegenerative ailment marked by a sustained loss of dopaminergic neurons from brain stem. The pathology of the disease is based on degeneration of dopaminergic neurons and attendant decrease in dopamine levels in dense region of substantia nigra [8]. Statistics show that PD is prevalent among older adults (age $\geq 60$ years), with total incidence of $1-2 \%$. The pathogenesis of PD is complex, and its diagnosis is based mainly on clinical manifestations presented.

Table 3: Levels of inflammatory factors in brain tissues of mice with PD $(\mu \mathrm{g} / \mathrm{L})$

\begin{tabular}{llccc}
\hline Group & & IL-1 & IL-6 & TNF- $\alpha$ \\
\hline Normal & MiR-146a & $0.31 \pm$ & $1.26 \pm$ & $2.60 \pm$ \\
control & inhibitor & 0.02 & 0.02 & 0.04 \\
& Inhibitor & $0.32 \pm$ & $1.29 \pm$ & $2.62 \pm$ \\
& control & 0.01 & 0.03 & 0.05 \\
Parkinson's & MiR-146a & $0.40 \pm$ & $1.45 \pm$ & $3.20 \pm$ \\
disease & inhibitor & $0.01^{*}$ & $0.03^{*}$ & $0.06^{*}$ \\
& Inhibitor & $0.41 \pm$ & $1.47 \pm$ & $3.24 \pm$ \\
& control & $0.01^{*}$ & $0.02^{*}$ & $0.03^{*}$ \\
\hline
\end{tabular}

${ }^{*} P<0.05$, vs normal control

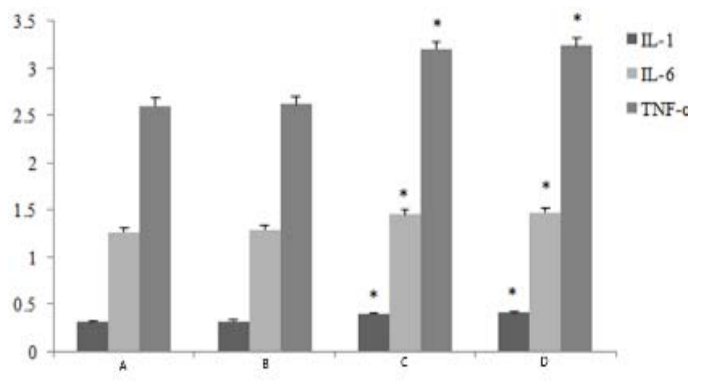

Figure 4: Levels of inflammatory cytokines in brain tissues of mice with PD. A. Normal control - miR-146a inhibitor; B. Normal control - Inhibitor control; C. Parkinson's disease - miR-146a inhibitor; D. Parkinson's disease -Inhibitor control. ${ }^{*} P<0.05$, compared with normal control group

In recent times, pathogenic genes have been associated with PD [9]. The involvement of miRNAs in the pathogenesis of PD has been reported [9]. MicroRNAs (miRNAs) are noncoding RNAs which possess regulatory function. These miRNAs which contain approximately 20 24 nucleotides, exist freely in cells. MicroRNAs (miRNAs) participate in the regulation of gene transcription via complementary binding to $3^{\prime}$ untranslated region ( $3^{\prime}$ UTR) of the gene. Their interactions with genes inhibit or induce mRNA degradation, thereby affecting the stability of mRNA.

Studies have shown that miRNA genes make up one-third of the human genome [10,11]. While a single miRNA can regulate multiple target genes, multiple miRNAs may combine to regulate a single target gene. MicroRNA-mediated gene expression are vital in the maintenance of normal cell division cycle, apoptosis and intermediary metabolism [12]. It has been reported that 
multiple miRNAs participate in the pathogenesis of PD [13]. The mechanism involved in posttranscriptional regulation by miRNA has been demonstrated to be involved in the pathogenesis of PD, and it is thought to serve as sensitive index for diagnosis of PD as well as evaluation of disease progression and prognosis [14].

MicroRNA-146a (miR-146a) is an NF-KBdependent molecule located on chromosome 5 in humans. Indeed, miR-146a is an immunemodulatory molecule implicated in tumorigenesis and inflammatory response, and it is abnormally expressed in a variety of nervous system tumors. A study has reported that miR-146a was markedly lower in cerebrospinal fluid (CSF) of PD subjects than in normal healthy patients [15].

Interleukin-1 receptor-associated kinase-1 (IRAK-1) gene which encodes 712 amino acids, is located on chromosome Xq28. Its 3' UTR and exon region with two polymorphism loci (rs3027898 and rs1059703), promote NF-kB activation. Polymorphism in IRAK1 is associated with increased susceptibility to certain diseases such as whooping cough and systemic lupus erythematosus (SLE) [16]. Studies have shown that miR-146a exerts its role in disease via regulation of IRAK-1 gene. In addition, miR-146a suppresses inflammation via mechanisms involving inhibition of NF-kB pathway and downregulation of IRAK-1 protein expression [17].

The present study has demonstrated that miR146a expression level was significantly and timedependently increased in PD mice, relative to normal control group, an indication that miR146a may be implicated in the etiology of PD. In PD mice, IRAK-1 mRNA and protein expression levels were markedly higher in miR-146a inhibitor group than in inhibitor control group. Similarly, P65-NF-kB protein, IL-1, TNF- $\alpha$ and IL-6 in brains of mice with $P D$ were markedly higher than those in normal control mice, an indication that miR-146a may negatively regulate IRAK-1 gene and activate NF-KB pathway downstream via regulation of expression of related inflammatory cytokines. Results of previous studies show that the promoter region of miR146a contains a binding site for NF-KB, which enhances the transcription of miR-146a, while downregulating IRAK1 protein expression [1719].

\section{CONCLUSION}

The results obtained in this study show that miR$146 a$ is implicated in the etiology of PD, and its regulation of neuroinflammation occurs via inhibition of IRAK-1 gene expression. This finding may be useful in the quest for new anti-PD drugs based on miR-146a.

\section{DECLARATIONS}

\section{Acknowledgement}

Ningxia Hui Autonomous Region Key Research and Development Program (no. 2017) and Ningxia Natural Science Foundation Project (no. NZ17189) supported this research.

\section{Conflict of interest}

No conflict of interest is associated with this work.

\section{Contribution of authors}

We declare that this work was performed by the authors named in this article and all liabilities pertaining to claims relating to the content of this article will be borne by the authors. Jiangtao Guo designed the study, supervised the data collection, and analyzed the data. Xuqing Cao interpreted the data and prepared the manuscript for publication. Hidek Mochizuki, Zhimin Shi, Peilan Zhang, Zhimei Liu, Tao Zhang, Jinxi Qi and Dong $\mathrm{Xu}$ supervised the data collection, analyzed the data and reviewed the draft of the manuscript. Xuqing Cao, Jiangtao Guo contributed equally to this work as co-first author.

\section{Open Access}

This is an Open Access article that uses a funding model which does not charge readers or their institutions for access and distributed under the terms of the Creative Commons Attribution License (http://creativecommons.org/licenses/by/ 4.0) and the Budapest Open Access Initiative (http://www.budapestopenaccessinitiative.org/rea d), which permit unrestricted use, distribution, and reproduction in any medium, provided the original work is properly credited.

\section{REFERENCES}

1. Aoyama K, Matsubara K, Okada K, Fukushima S, Shimizu K, Yamaguchi S, Uezono T, Satomi M, Hayase $N$, Ohta $S$, et al. N-methylation ability for azaheterocyclic amines is higher in Parkinson's disease: nicotinamide loading test. J Neural Transm (Vienna) 2000; 107(8-9): 985-995.

2. Stefani A, Hogl B. Sleep in Parkinson's disease. Neuropsychopharmacology 2020; 45(1): 121-128. 
3. Stella F, Banzato CEM, Quagliato EMAB, Viana MA, Christofoletti G. Dementia and functional decline in patients with Parkinson's disease. Dement Neuropsychol 2008; 2(2): 96-101.

4. Dos Santos MCT, Barreto-Sanz MA, Correia BRS, Bell R, Widnall $C$, Perez $L T$, Berteau $C$, Schulte $C$, Scheller $D$, Berg D, Maetzler W, Galante PAF, Nogueira da Costa A. miRNA-based signatures in cerebrospinal fluid as potential diagnostic tools for early-stage Parkinson's disease. Oncotarget 2018; 9(25):17455-17465.

5. Schwienbacher C, Foco L, Picard A, Corradi E, Serafin A, Panzer J, Zanigni S, Blankenburg $H$, Facheris MF, Giannini G, et al. Plasma and White Blood Cells Show Different miRNA Expression Profiles in Parkinson's Disease J Mol Neurosci; 62(2): 244-254.

6. Kwon D, Liew H. miRNA profile of neuroprotection mechanism of echinomycin in Parkinson's disease. Mol Cell Toxicol 2017; 13 (2): 229 - 238.

7. World Health Organization. Principles of laboratory animal care. WHO Chron 1985; 39: 51-56.

8. Armstrong RA. Visual Dysfunction in Parkinson's Disease. Int Rev Neurobiol 2017; 134: 921-946.

9. Tarakad A, Jankovic J. Diagnosis and Management of Parkinson's Disease. Semin Neurol 2017; 37(2): 118126.

10. Ciceri $F$, Rotllant D, Maes T. Understanding Epigenetic Alterations in Alzheimer's and Parkinson's Disease: Towards Targeted Biomarkers and Therapies. Curr Pharm Des 2017; 23(5): 839-857.

11. Uwatoko H, Hama Y, Iwata IT, Shirai S, Matsushima M, Yabe I, Utsumi J, Sasaki H. Identification of plasma microRNA expression changes in multiple system atrophy and Parkinson's disease. Mol Brain 2019; 12(1): 49.

12. Li D, Yang H, Ma J, Luo S, Chen S, Gu Q. MicroRNA-30e regulates neuroinflammation in MPTP model of
Parkinson's disease by targeting NIrp3. Hum Cell 2018; 31(2): 106-115.

13. Leggio L, Vivarelli S, L'Episcopo F, Tirolo C, Caniglia S, Testa N, Marchetti B, Iraci N. microRNAs in Parkinson's Disease: From Pathogenesis to Novel Diagnostic and Therapeutic Approaches. Int J Mol Sci 2017; 18(12): 2698.

14. Zheng CZ, Shu YB, Luo YL, Luo J. The role of miR-146a in modulating TRAF6-induced inflammation during lupus nephritis. Eur Rev Med Pharmacol Sci 2017; 21(5): 1041-1048.

15. Lee HW, Khan SQ, Khaliqdina S, Altintas $M M$, Grahammer F, Zhao JL, Koh KH, Tardi NJ, Faridi MH, Geraghty $T$, et al. Absence of miR-146a in Podocytes Increases Risk of Diabetic Glomerulopathy via Upregulation of ErbB4 and Notch-1. J Biol Chem 2017; 292(2): 732-747.

16. Assmann TS, Duarte GCK, Brondani LA, de Freitas PHO, Martins ÉM, Canani LH, Crispim D. Polymorphisms in genes encoding miR-155 and miR-146a are associated with protection to type 1 diabetes mellitus. Acta Diabetol 2017; 54(5):433-441.

17. Hassine HB, Boumiza A, Sghiri R, Baccouche $K$, Boussaid I, Atig A, Shakoor Z, Bouajina E, Zemni R. Micro RNA-146a But Not IRAK1 is Associated with Rheumatoid Arthritis in the Tunisian Population. Genet Test Mol Biomarkers 2017; 21(2):92-96.

18. Liu B, Zhao G, Jin L, Shi J. Nicotinamide Improves Cognitive Function in Mice With Chronic Cerebral Hypoperfusion. Front Neurol 2021; 12: 596641.

19. Li D, Lixia Y, Fengsui L, Haitao Z, Xinwei C. Farrerol ameliorates diabetic hepatopathy in rat model of type 2 diabetes mellitus via modulation of oxidativeinflammatory stress. Trop J Pharm Res 2020; 19 (1): 71 76. 